\title{
The Impact of the Structure of the Education System on the Development of Educational Inequalities in the Czech Republic*
}

\author{
JANA STRAKOVÁ** \\ Institute of Sociology, Academy of Sciences of the Czech Republic, Prague
}

\begin{abstract}
The aim of this paper is to explore the impact of the structure of the Czech education system on the development of the relationship between a student's achievement and his/her family background. It compares the strength of the relationship between student achievement and a student's family background in various stages of his/her education career (grades 4, 8 and 10) in the Czech Republic and in systems without early tracking that also exhibit high student performance (Canada, Nordic countries). In addition, the paper tests a hypothesis that systems with different levels of tracking differ not only in their structure but also in teaching methods and teachers' attitudes. The analysis was conducted on data sets from the IEA PIRLS 2001, the IEA TIMSS 1999, and the OECD PISA 2003.
\end{abstract}

Keywords: student achievement, socio-economic status, selectivity of education system, teaching attitudes

Sociologický časopis/Czech Sociological Review, 2007, Vol. 43, No. 3: 589-610

\section{Introduction}

All advanced countries show a correlation between a student's achievement and his/her family background. Students from a more advantaged home background tend to have higher test scores. However, the influence of social origin and family background on student achievement varies in strength between individual systems. The comparisons of the relationship between student performance and the various aspects of socio-economic background also show that some countries simultaneously demonstrate high average quality and relatively high equality of outcomes among students from different socio-economic backgrounds. There-

\footnotetext{
* The preparation of this paper was made possible thanks to the project 'Unequal Access to Education: The Extent, Sources, Social and Economic Consequences, Policy Strategies' (Grant No. IJ005/04-DP2 of the Ministry of Labour and Social Affairs of the Czech Republic).

** Direct all correspondence to: Jana Straková, Department of Education and Social Stratification, Institute of Sociology, Academy of Sciences of the Czech Republic, Jilská 1, 11000 Prague 1, Czech Republic, e-mail: jana.strakova@soc.cas.cz.
} 
fore, wide disparities in student performance are not a necessary condition for a country to attain a high level of overall performance [OECD 2001; 2004a; 2005b; 2006].

Alongside factors related to academic ability and educational performance (genetic factors, differences in children's home environments, class and cultural bias at school, and difference in health and nutrition), the most frequently studied factors behind the interdependence of a student's achievement and his/her family background relate to transition odds. These are significantly influenced by the structure of the education system, its differentiation, and the age at the time of the first selection. In early selection parents are more influential. Educated parents value education and understand the education system. They can give advice on strategies that are not likely to constrain later choices. Lower-class children experience less encouragement from their background family. In a system in which early self-selection is constrained by the choice structure there is less educational inequality than in a system where consequential decisions about the educational career are taken at a very young age [Erikson and Jonsson 1996].

Analyses of data from international achievement surveys repeatedly show that wider socio-economic differences in performance are associated with school systems that differentiate students into different schools or programmes. These results also suggest that more inclusive schooling systems also have higher performance levels [OECD 2004a; 2005b; 2006]. Findings from international achievement surveys correspond to the results of the research on ability grouping that confirm the absence of favourable effects linked to homogenous groupings. In an experimental situation where the pedagogic variables are objects of strict control, homogenous grouping does not produce different effects according to the levels of constituents groups; classes that admit only good students do not progress more than classes composed essentially of weak students. However, this grouping is accompanied by differentiation in curriculum, by the fact that the best teachers teach the classes attended by the best students, and by pedagogical practices that favour those students. Inequalities in the type of pupil/teacher interaction serve to widen the gap between the higher and lower achievement classes. In addition, student allocation is often influenced by factors other than student ability, and early allocation to sets is discouraging for students with lower attainment [Hutchmaker, Cochrane and Bottani 2001; Harlen and Malcolm 1999; Slavin 1990]. Student composition affects school climate. When explaining performance variation among schools, there is a far stronger joint association between the school climate and the contextual factors than there is between either school policies or school resources and the contextual factors. School climate may be strongly influenced by the norms and values that students bring to the school, which in turn may be closely associated with the students' socio-economic background [OECD 2005b].

The argument that the selection of students, especially when it occurs at an early age, is social discrimination and thus contributes to the reproduction of educational inequalities has prompted a number of countries to change from a 
diversified to a unified system ${ }^{1}$ [OECD 2004a]. In the majority of European and OECD countries the first selection process currently occurs no earlier than at the age of fifteen [OECD 2005a]. For example, the Finnish comprehensive school reform of 1972-1977 significantly reduced the degree of heterogeneity in Finnish primary and secondary education. The reform shifted the tracking age in secondary education from age 10 to age 16 and imposed a uniform academic curriculum on entire cohorts until the end of lower secondary school. Reform reduced the intergenerational income correlation by seven percentage points [Pekkarinen, Uusitalo and Pekkala 2006]. In Sweden, studies have confirmed the decreasing influence of background factors, such as the parents' position in society, gender, and type of community, on educational attainment as a result of both educational and other welfare policies [Wildt-Persson and Rosengren 2001].

However, in order to maximise the education yield for all students and especially for those from low-status families, it is not enough to eliminate early tracking. Finnish experience shows that teachers have to be systematically prepared to teach in mix-ability classrooms [OECD 2004b]. Research shows that many mixed-ability classes are not taught in a way that caters for mixed ability; observation studies indicate that mixed-ability classes are often taught as if everyone were of the same ability and all of lower than average ability [Harlen and Malcolm 1999].

\section{The situation in the Czech Republic}

In most international comparative studies of student achievement, Czech students at the age of compulsory schooling typically tend to achieve relatively high average performance [Beaton et al. 1997a, 1997b; Martin et al. 1997; Mullis et al. 1997, 2000a, 2000b, 2003; OECD 2001, 2004a]. At the same time, the Czech Republic exhibits a relatively strong relationship between student achievement and family background [OECD 2001; 2004a].

The Czech education system appears to be very selective; selection starts at a very young age. Czech students can take their first entrance examinations at the age of eight, when they apply for admissions to classes or schools with extended curricula of foreign languages. ${ }^{2}$ The next selection occurs at the age of eleven or thirteen when fifth- or seventh-grade students (10\% of the age cohort) move to a multi-year gymnasium (a long academic secondary track). In addition, the country also features a high percentage of students who are educated separately in special education schools. ${ }^{3}$ Recently, schools and classrooms for 'gifted

\footnotetext{
${ }^{1}$ That means the elimination of tracking or its postponement to higher grades.

${ }^{2}$ Schools with extended curricula of any subject are attended by $10 \%$ of the age cohort.

${ }^{3}$ The Czech Republic is the only European country in which more than 5\% of students with special education needs are educated separately from the majority population in schools with reduced curricula [Key Data on Education... 2004].
} 
children' appeared in the system at the primary level. After finishing compulsory education, Czech students choose between an academic track at a four-year gymnasium (10\% of all secondary students), a secondary technical track (40\% of the age cohort), and a vocational track (40\%). (A diagram of the education system is included in Appendix A.) Students from academic and secondary technical tracks are entitled to apply for admission to university. However, only gymnasia prepare their students properly for the demanding entrance examinations that focus mainly on factual knowledge. The Czech Republic exhibits one of the lowest proportions of secondary students in general education [OECD 2005a]. It also has one of the lowest proportions of students in tertiary education; only $25 \%$ of the respective age cohort continues on to tertiary education. Both the choice of the upper secondary school and the consequent chances for successful transition to tertiary education are strongly affected by social origin [Matějů and Straková 2003; Matějů, Řeháková and Simonová 2003].

Psychologists believe that there are elements that enhance social differences that are born out of the teaching methods and the approach to students generally applied in the country's schools [e.g. Nováčková 2001]. Academically oriented frontal teaching methods prevent students from low-status families in particular from achieving some sense of self-fulfilment at school and from attaining success. Consequently, these methods have a powerfully de-motivating effect, especially in connection with the fact that Czech children receive very little individual support and care from their teachers at school [OECD 2004a].

The mechanism of the development of the relationship between a student's achievement and his/her family background in the Czech education system has not been studied systematically so far. The aim of the paper, therefore, is to shed some light on the mechanisms involved in the formation of educational inequalities related to the characteristics of the education system in the Czech Republic. I try to explore both factors related to the structure of the education system and those related to teaching attitudes. The analysis is based on data from international comparative surveys. The selection of indicators is limited by the variables included in those data sets.

\section{Research questions and hypotheses}

The goal is to find out to what extent tracking influences the level of inequality in educational achievement. First, it is beneficial to learn how the strength of the relationship between student achievement and student family background increases in higher grades as the tracking gets more pronounced. The strength of the relationship in different stages of the educational career of Czech students cannot be compared directly because no comparable data for different grades are available. The Czech Republic does not organise its own national achievement surveys. The only available data sets come from international comparative surveys organised 
by the International Association for the Evaluation of Educational Achievement and the OECD. These surveys study children in different stages of their school career. However, they use different indicators of family background and thus do not allow for a direct comparison of the strength of the relationship between student achievement and family background in different grades. The situation in the Czech Republic is thus illustrated in comparison with other countries. The strength of the relationship in the Czech Republic is compared with the strength of the relationship in countries that exhibit similar student achievement and similar variation in socio-economic background but do not track children until the age of 16. The extent to which the achievement of students in individual schools is influenced by the composition of students in these schools is also studied. The reference countries selected were Canada, Sweden, and Finland. ${ }^{4}$ These countries have high achievement and relatively low variation in socio-economic background and switched from a tracked system to a non-tracked one in order to reduce the level of inequalities in the systems [OECD 2004a, 2004b; EGREES 2006].

The paper concentrates on the following questions:

- What are the differences in the relationship between student achievement and family background in the Czech Republic, Sweden, Finland, and Canada in various stages of the educational career?

- What is the effect of the social composition of students in individual schools on student achievement in the Czech Republic, Sweden, Finland, and Canada?

The following hypotheses were formulated:

H1. At lower levels of the education system there is no significant difference in the steepness of the 'ses gradient ${ }^{\prime 5}$ in the Czech Republic, Sweden, and Canada. At higher levels of the education system the 'ses gradient' for the Czech Republic becomes steeper than in non-tracked countries: Sweden, Finland, and Canada.

H2. At higher levels of the education system the influence of the social composition of schools on the achievement of individual students is much higher in the Czech Republic than in countries with non-tracked education systems: Sweden, Finland, and Canada.

Research on the effect of tracking on student achievement [e.g. Slavin 1990; Harlen and Malcolm 1999] shows that it is useful to explore the extent to which

\footnotetext{
${ }^{4}$ Sweden participated in the IEA PIRL Study in grade 4, and Finland participated in the TIMS Study in grade 8. All countries participated in the OECD PISA in grades 9/10.

${ }^{5}$ The 'ses gradient' is a regression line between student achievement and the indicator of socio-economic status [Wilms 2003].
} 
various education systems adjust to individual student's needs. We pose the following question:

- $\quad$ Are there any differences in teaching methods and teacher attitudes in countries that track students early and those that do not?

To answer this question the full set of available OECD countries was used. The question leads to the following hypothesis:

H3. Non-tracked education systems give more support to students with educational difficulties than education systems with early tracking.

\section{Data, variables, and the methods of the analysis}

The analysis was conducted on data sets from the IEA PIRLS 2001, the IEA TIMSS $1999^{6}$ and the OECD PISA 2003. In the IEA studies the samples were grade-based, the IEA PIRLS focused on grade 4 and the IEA TIMSS on grade 8 . In the OECD study the sample was age-based. ${ }^{8}$ In the analysis of the PISA 2003 data students from the grade with highest representation were included: grade 10 for Canada (82.2\% of students in the sample) and the Czech Republic (52.4\% of students in the sample) $)^{9}$ and Grade 9 for Finland (87.7\% of students in the sample) and Sweden $(93.0 \%$ of students in the sample). For the Czech Republic the national data sets were used, in which, unlike the international data sets, variables enabling the identification of different types of schools were retained..$^{10}$

\footnotetext{
${ }^{6}$ Progress in International Reading Literacy Study, Trends in International Mathematics and Science Study. The full PIRLS 2001 and TIMSS 1999 data sets are available at http:// www.timss.org/.

7 Programme for International Student Assessment. The full data set is available at http:// www.pisa.oecd.org/.

${ }^{8}$ Samples were selected in two stages: first, schools in each stratum were randomly selected then students from these schools (in the OECD study), and respectively classes in the particular grade (in the IEA studies) were randomly selected.

${ }^{9}$ In the Czech Republic all students born after September 1 enter school a year later, and a one-year postponement is sought every year also by $25 \%$ of the age cohort born before September 1. Usually parents wish their children to enter school later because they believe that older children will be able to face school demands more easily. Although the PISA sample was not constructed as representative for grade 10 students, various checks of its composition showed that it represents well the population of students in their first year of secondary studies. The composition of students in the respective grades is not biased by grade retention. The retention rate at a compulsory level is very low in the Czech Republic (about $0.6 \%$ ).

${ }^{10}$ In the IEA studies students attending special education schools were excluded from the sample. In the PIRLS sample students attended either common basic schools or schools with extended curricula. In the TIMSS sample students attended common basic schools,
} 
The relationships between student achievement and socio-economic background were studied by socio-economic gradients [Wilms 2003] and by hierarchical linear modelling. Hierarchical linear models were applied because the data used in the analysis was collected using a 'cluster' sampling method - first the schools were randomly selected and then the students in those schools. The observations made in individual schools thus tend to be more similar than would be the case in a simple random sample of students [Wilms 1999].

The measures of socio-economic status were constructed from variables included in questionnaires distributed to students and parents ${ }^{11}$ and were not identical in all surveys. In the PIRLS, a composite measure, based on highest parental education, the main job of the mother, and the main job of the father, ${ }^{12}$ was used as an indicator of the socio-economic status of a child. In the TIMSS, the indicator of socio-economical status was constructed from highest parental education, the number of books at home, and possession of a computer and a dictionary. ${ }^{13}$ In the PISA study, the international index of economic, social, and cultural status ESCS was used as a measure of the background characteristics of the students. ${ }^{14}$

In all data sets plausible values ${ }^{15}$ [Hambleton, Swaminathan and Rogers 1991] were used as the measure of student performance. In the PIRLS plausible values of overall reading performance were used and in the TIMSS and the PISA 2003 plausible values of overall mathematics performance. Socio-economic gradients demonstrating the relationship between a student's achievement and his/her socio-economic status were constructed using the mean value of the plausible values. ${ }^{16}$ Hierarchical linear models exploring the influence of socio-eco-

schools with extended curricula or multi-year gymnasia. The PISA sample included students in grade 9 (ISCED 2) and grade 10 (ISCED 3). In our analysis only students attending grade 10 were included. They attended special education schools, vocational schools, technical schools, four-year gymnasia, or multi-year gymnasia.

11 The PIRLS also included a questionnaire for parents.

12 The index was constructed by factor analysis from the variables asdhedup, asbhmjf, asbhmjm from the parental questionnaire. The proportion of cases with a missing index: Canada 30\%, Sweden 19.7\%, the Czech Republic 27.1\%.

${ }^{13}$ Variables bsbgbook, bsbgps02, bsbgps04, bsbgedmo, bsbgedfa from the student questionnaire. The proportion of cases with a missing index: Canada 1.5\%, Czech Republic $18.8 \%$, Finland $54.5 \%$.

${ }^{14}$ The ESCS index was constructed using the Item Response Theory methodology and included the following variables: the highest parental international index of professional status (ISEI), the highest parental education, family wealth, the availability of educational resources in a family, and cultural possessions. The proportion of cases with missing index was in all countries below $1 \%$.

${ }^{15}$ In all respective studies rotated booklet design was used. Achievement estimates (plausible values) were estimated as a sample of scores from the distribution of student abilities. The distribution of student abilities was determined using Item Response Theory methodology (the Rasch model).

${ }_{16}$ The results obtained with averaged plausible values (PV) were verified with calculations using first plausible values. Both procedures gave the same results. 
nomic status on student achievement at the individual and the school level in different grades were estimated with each plausible value and then averaged. Data was weighted by the final student weight included in all data sets.

For the analysis of differences in teaching methods and attitudes between education systems with different levels of tracking, variables from student and teacher questionnaires ${ }^{17}$ were used: the availability of differentiated reading materials, the availability of teaching aids, the availability of reading specialists (variables atbgumat, atbgdif1, atbgdif3 in the PIRLS teacher questionnaire), the interest of teachers in every student learning and teacher help, the index of teacher support (variables st38q01, st38q03, st38q05, st38q07, st38q10 in the PISA student questionnaire), the teacher's belief that some students are gifted and others are not (variable btbsagr4 in the TIMSS teacher questionnaire).

As an indicator of the differentiation of the education system the age of the first selection in the education system was used [OECD 2005a]. The mean values of indicators were compared for groups of countries with different ages at the time of the first selection in the education system. All countries included in the analysis participated in the OECD PISA, but only some of them contributed to indicators gained from the IEA studies. ${ }^{18}$

\section{Results of the analysis}

Development of the relationship between a student's achievement and his/her socioeconomic status in different education systems

Table 1 shows the mean achievement score and its standard deviation for countries included in the analysis and the mean and standard deviation of the index of economic social and cultural status escs constructed in the PISA. The table shows that the Czech Republic has comparable variation in escs with other countries and also comparable variation in reading achievement in grade 4 . In higher grades, the variation in achievement is higher than in Finland and Canada.

Figures 1-3 show the socio-economic gradients for different grades. While in grade 4 the slope of the gradient in the Czech Republic does not differ significantly from the slopes of Sweden and Canada, in grade 8 and grade $9 / 10$ there is a statistically significant difference between the slope of the gradient in the Czech Republic and all other countries.

${ }_{17}$ Only the IEA studies also administer questionnaires for teachers.

18 OECD countries for which information about the first selection was available from Education at a Glance 2005 participating in the IEA studies: IEA PIRLS - Canada, Czech Republic, France, Germany, Greece, Hungary, Iceland, Italy, Netherlands, New Zealand, Norway, Slovak Republic, Sweden, Turkey, United Kingdom, United States. The IEA TIMSS - Australia, Belgium, Canada, Czech Republic, Finland, Hungary, Italy, Japan, Netherlands, New Zealand, Slovak Republic, Turkey, United Kingdom, United States. 
Table 1. Countries in the analysis: achievement score, standard deviation and index of economic social and cultural status $^{19}$

\begin{tabular}{|c|c|c|}
\hline & Mean (se) & SD (se) \\
\hline $\begin{array}{l}\text { PIRLS } \\
\text { (grade 4) }\end{array}$ & Reading & \\
\hline CZE & $537(2,3)$ & $65(1,4)$ \\
\hline CAN & $544(2,4)$ & $72(1,0)$ \\
\hline SWE & $561(2,2)$ & $66(1,2)$ \\
\hline International average & $500(0,6)$ & \\
\hline $\begin{array}{l}\text { TIMSS } \\
\text { (grade 8) }\end{array}$ & Math & \\
\hline CZE & $520(4,2)$ & $79(2,4)$ \\
\hline CAN & $531(2,5)$ & $73(1,7)$ \\
\hline FIN & $520(2,7)$ & $65(1,3)$ \\
\hline International average & $487(0,7)$ & \\
\hline $\begin{array}{l}\text { PISA } \\
\text { (grade 9/10) }\end{array}$ & Math & \\
\hline CZE & $516(3,5)$ & $96(1,9)$ \\
\hline CAN & $532(1,8)$ & $87(1,0)$ \\
\hline FIN & $544(1,9)$ & $84(1,1)$ \\
\hline SWE & $509(2,6)$ & $95(1,3)$ \\
\hline International average & $500(0,6)$ & \\
\hline \multicolumn{3}{|l|}{ SES (PISA) } \\
\hline CZE & $0,16(0,02)$ & $0,80(0,01)$ \\
\hline CAN & $0,45(0,02)$ & $0,83(0,01)$ \\
\hline FIN & $0,25(0,02)$ & $0,83(0,01)$ \\
\hline SWE & $0,25(0,02)$ & $0,88(0,01)$ \\
\hline
\end{tabular}

Source: PIRLS 2001, TIMSS 1999, PISA 2003.

${ }^{19}$ PISA reading scores for countries in the analysis were as follows: Finland 543, Canada 528, Sweden 514 and Czech Republic 489. 
Figure 1. Relationship between a student's achievement and his/her socio-economic status in grade 4

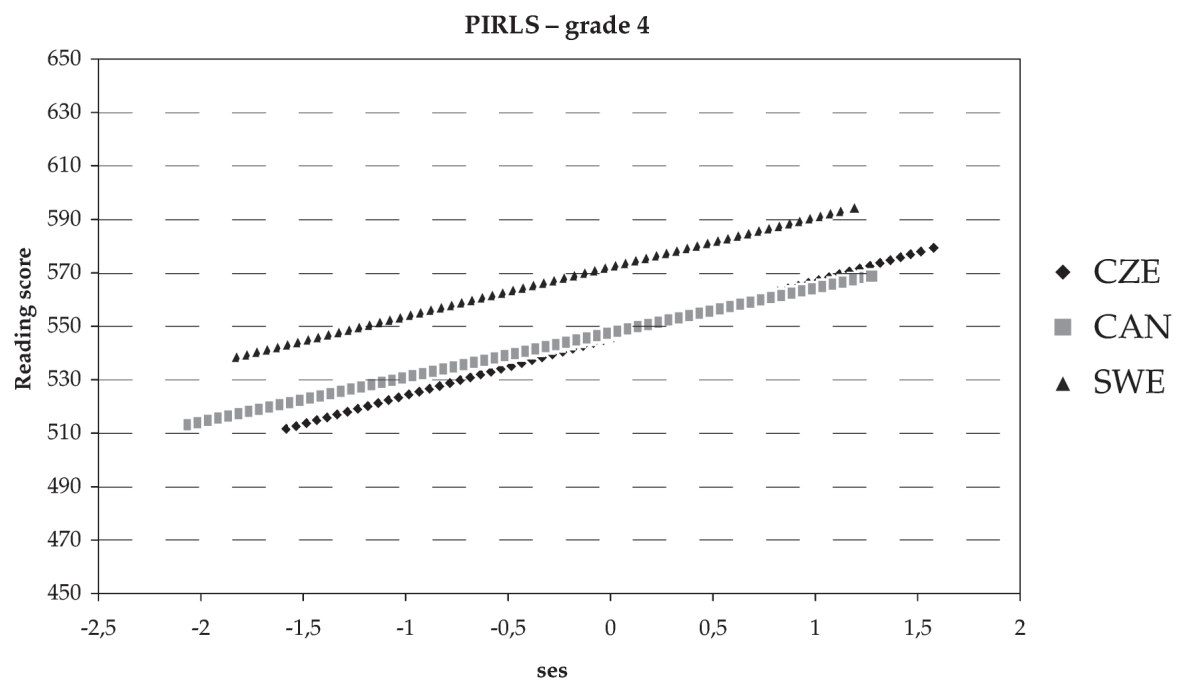

CZE: $y=21,4 x+545,5 \quad$ CAN: $y=16,7 x+547,5 \quad$ SWE: $y=18,5 x+572,5$

Figure 2. Relationship between a student's achievement and his/her socio-economic status in grade 8

TIMSS - grade 8

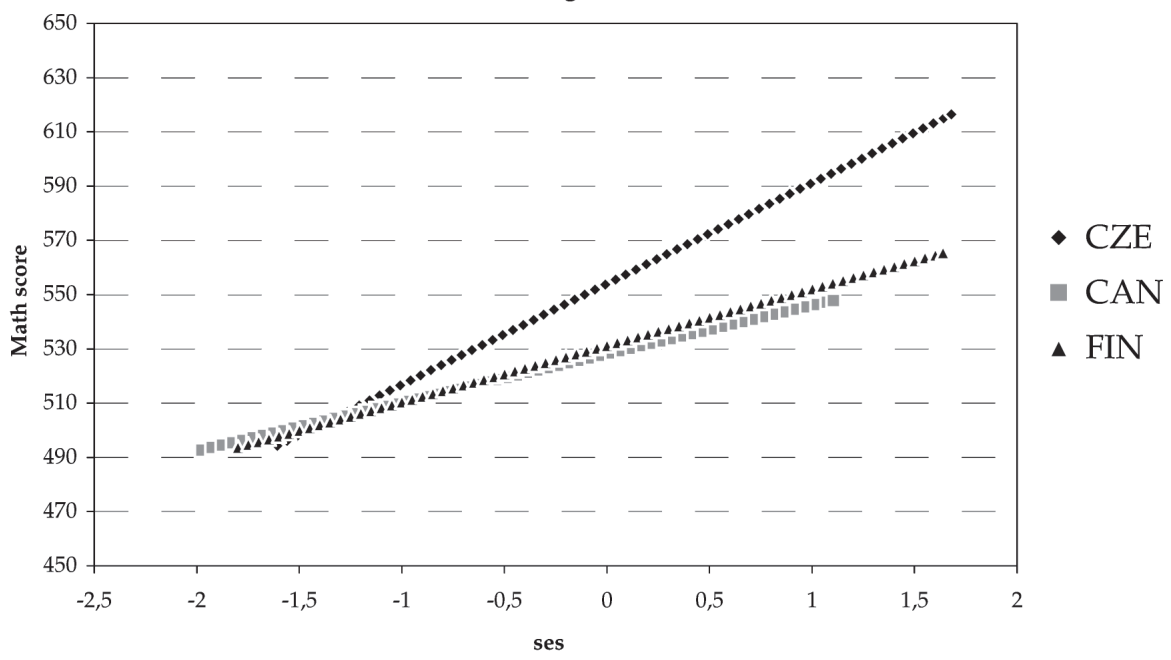

CZE: $y=37,1 x+554,0 \quad$ CAN: $y=17,9 x+528,0 \quad$ FIN: $y=20,8 x+531,3$ 
Figure 3. Relationship between a student's achievement and his/her socio-economic status in grade $9 / 10$

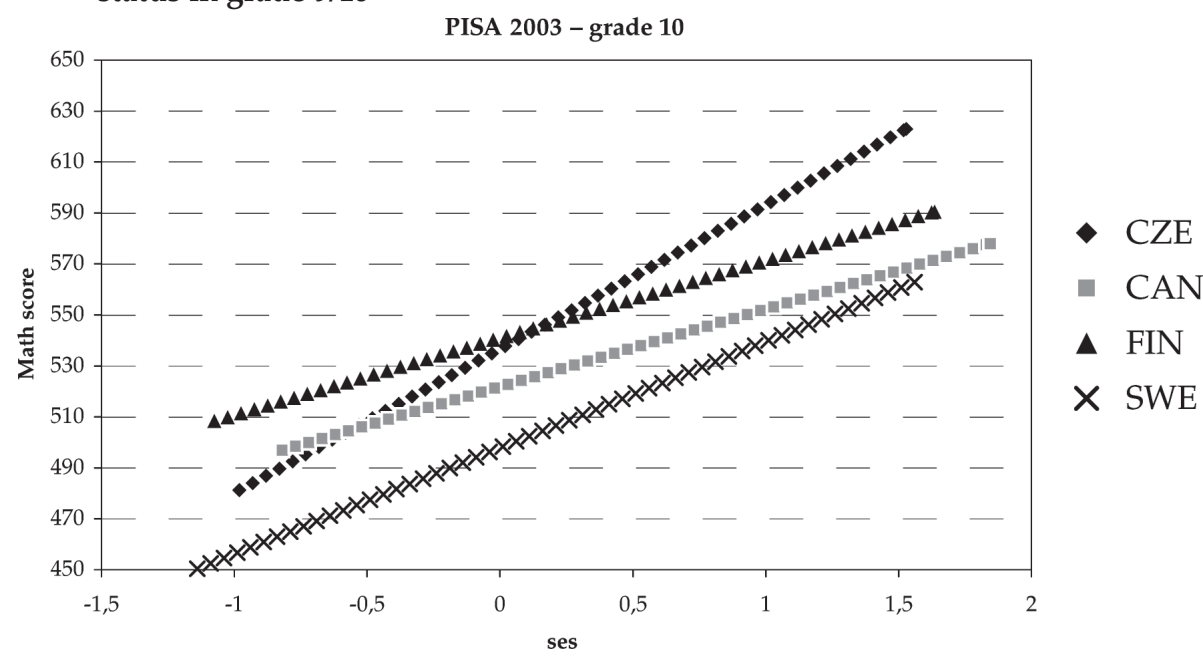

CZE: $y=56,5 x+536,7 \quad$ CAN: $y=30,4 x+521,8 \quad$ FIN $: y=30,3 x+541,0 \quad$ SWE: $y=41,7 x+497,9$

The results confirm the first hypothesis: At the level of ISCED 1, where the tracking is still indistinctive, the strength of the relationship between student achievement and student family background in the Czech Republic is comparable to that in Canada and Sweden. In higher grades with more pronounced tracking, the differences in the strength of relationship between student achievement and student family background between the Czech Republic and countries with non-tracked education systems (Finland, Canada, Sweden) grow. At the same time, in comparison with Finland and Canada, the overall variation in student achievement increases.

Impact of the composition of students in individual schools on student achievement

Tables 2-4 show for respective grades the intra-class correlation for student performance for all countries in the analysis. They also show the results of multilevel models with socio-economic status at both the student and the school level. ${ }^{20}$ In grade 4, the influence of socio-economic status at the school level is not statistically significant in the Czech Republic. In grades 8 and 10 it is statistically significant and much higher than in other countries and than the influence of socio-econom-

${ }^{20}$ At the student level the explanatory variables were group-centred, at the school level the variables were grand-centred. 
Table 2. Hierarchical linear models for grade 4 (PIRLS)

\begin{tabular}{|c|c|c|c|c|c|}
\hline & $\%$ & & coeff & se & sig \\
\hline \multicolumn{6}{|l|}{ CZE } \\
\hline \multirow[t]{3}{*}{ Intra class correlation read $* 100$} & \multirow[t]{3}{*}{16.4} & intercpt 2, G0 & 545,4 & 2,2 & 0,000 \\
\hline & & SES_school level & 7,3 & 5,4 & 0,183 \\
\hline & & SES_student level & 17,9 & 1,5 & 0,000 \\
\hline \multicolumn{6}{|l|}{ CAN } \\
\hline \multirow[t]{3}{*}{ Intra class correlation read * 100} & \multirow[t]{3}{*}{18.6} & intercpt 2, G0 & 557,4 & 1,9 & 0,000 \\
\hline & & SES_school level & 18,7 & 3,8 & 0,000 \\
\hline & & SES_student level & 14,2 & 1,3 & 0,000 \\
\hline \multicolumn{6}{|l|}{ SWE } \\
\hline \multirow[t]{3}{*}{ Intra class correlation read * 100} & \multirow[t]{3}{*}{15.5} & intercpt 2, G0 & 570,8 & 1,9 & 0,000 \\
\hline & & SES_school level & 12,7 & 3,6 & 0,001 \\
\hline & & SES_student level & 13,4 & 1,2 & 0,000 \\
\hline
\end{tabular}

Table 3. Hierarchical linear models for grade 8 (TIMSS)

\begin{tabular}{|c|c|c|c|c|c|}
\hline & $\%$ & & coeff & se & sig \\
\hline \multicolumn{6}{|l|}{ CZE } \\
\hline \multirow[t]{3}{*}{ Intra class correlation math * 100} & \multirow[t]{3}{*}{31.9} & intercpt 2, G0 & 540,2 & 5,1 & 0,000 \\
\hline & & SES_school level & 36,0 & 8,6 & 0,000 \\
\hline & & SES_student level & 16,4 & 2,3 & 0,000 \\
\hline \multicolumn{6}{|l|}{ CAN } \\
\hline \multirow[t]{3}{*}{ Intra class correlation math $* 100$} & \multirow[t]{3}{*}{26.3} & intercpt 2, G0 & 531,5 & 4,0 & 0,000 \\
\hline & & SES_school level & 9,9 & 5,8 & 0,089 \\
\hline & & SES_student level & 14,3 & 8,4 & 0,000 \\
\hline \multicolumn{6}{|l|}{ FIN } \\
\hline \multirow[t]{3}{*}{ Intra class correlation math * 100} & \multirow[t]{3}{*}{13.4} & intercpt 2, G0 & 530,0 & 3,1 & 0,000 \\
\hline & & SES_school level & 14,5 & 6,2 & 0,021 \\
\hline & & SES_student level & 17,9 & 2,2 & 0,000 \\
\hline
\end{tabular}


Table 4. Hierarchical linear models for grade 10 (PISA)

\begin{tabular}{|c|c|c|c|c|c|}
\hline & $\%$ & & coeff & se & $\operatorname{sig}$ \\
\hline \multicolumn{6}{|l|}{ CZE } \\
\hline \multirow[t]{3}{*}{ Intra class correlation math * 100} & \multirow[t]{3}{*}{56.5} & intercpt 2, G0 & 552,2 & 3,6 & 0,000 \\
\hline & & SES_school level & 111,3 & 8,3 & 0,000 \\
\hline & & SES_student level & 9,2 & 2,4 & 0,000 \\
\hline \multicolumn{6}{|l|}{ CAN } \\
\hline \multirow[t]{3}{*}{ Intra class correlation math $* 100$} & \multirow[t]{3}{*}{20.5} & intercpt 2, G0 & 541,4 & 1,9 & 0,000 \\
\hline & & SES_school level & 26,2 & 5,1 & 0,000 \\
\hline & & SES_student level & 23,5 & 1,4 & 0,000 \\
\hline \multicolumn{6}{|l|}{ FIN } \\
\hline \multirow[t]{3}{*}{ Intra class correlation math $* 100$} & \multirow[t]{3}{*}{4.5} & intercpt 2, G0 & 551,5 & 1,7 & 0,000 \\
\hline & & SES_school level & $-0,1$ & 5,8 & 0,985 \\
\hline & & SES_student level & 30,1 & 1,5 & 0,000 \\
\hline \multicolumn{6}{|l|}{ SWE } \\
\hline \multirow[t]{3}{*}{ Intra class correlation math * 100} & \multirow[t]{3}{*}{8.8} & intercpt 2, G0 & 510,2 & 1,9 & 0,000 \\
\hline & & SES_school level & 27,6 & 8,0 & 0,001 \\
\hline & & SES_student level & 37,0 & 2,0 & 0,000 \\
\hline
\end{tabular}

ic status at the student level. In other countries, the influence of ses at the school level is lower or comparable to ses at the student level. Results confirm the second hypothesis. The effect of the social composition of students in individual schools is much higher in the Czech Republic than in Sweden, Finland, and Canada.

Table 5 shows the mean achievement and socio-economic status for individual school types in the respective grades. The differences in both performance scores and indices of socio-economic status between individual school types are statistically significant at all grade levels. The impact of socio-economic status at the school level in the Czech education system is well demonstrated also on the school profiles of Czech schools presented in Figures 4-6 for respective grades and school types. Each school is represented by one dot. Selective schools are shifted towards both high achievement and high socio-economical status of their students. 
Table 5. Mean achievement and socio-economic status for individual school types and grades, Czech Republic

\begin{tabular}{llcc}
\hline Grade & & $\begin{array}{c}\text { Mean achieve- } \\
\text { ment }(\mathrm{se})\end{array}$ & $\begin{array}{c}\text { Mean socio-economic } \\
\text { status }(\mathrm{se})\end{array}$ \\
\hline Grade 4 & Basic schools & $535(0,2)$ & $-0,071(0,004)$ \\
& Schools with extended curricula & $592(0,9)$ & $0,716(0,024)$ \\
Grade 8 8 & Basic schools & $513(0,2)$ & $-0,140(0,003)$ \\
& Schools with extended curricula & $578(0,7)$ & $0,472(0,010)$ \\
& Multi-year gymnasia & $617(0,6)$ & $0,759(0,008)$ \\
Grade 10 & Special schools & $413(1,6)$ & - \\
& Vocational schools & $458(0,5)$ & $-0,319(0,050)$ \\
& Technical schools & $541(0,4)$ & $0,181(0,004)$ \\
& 4-year gymnasia & $610(0,7)$ & $0,732(0,009)$ \\
& Multi-year gymnasia & $637(0,8)$ & $0,921(0,010)$ \\
\hline
\end{tabular}

Figure 4. School profiles for Czech schools for grade 4 (PIRLS)

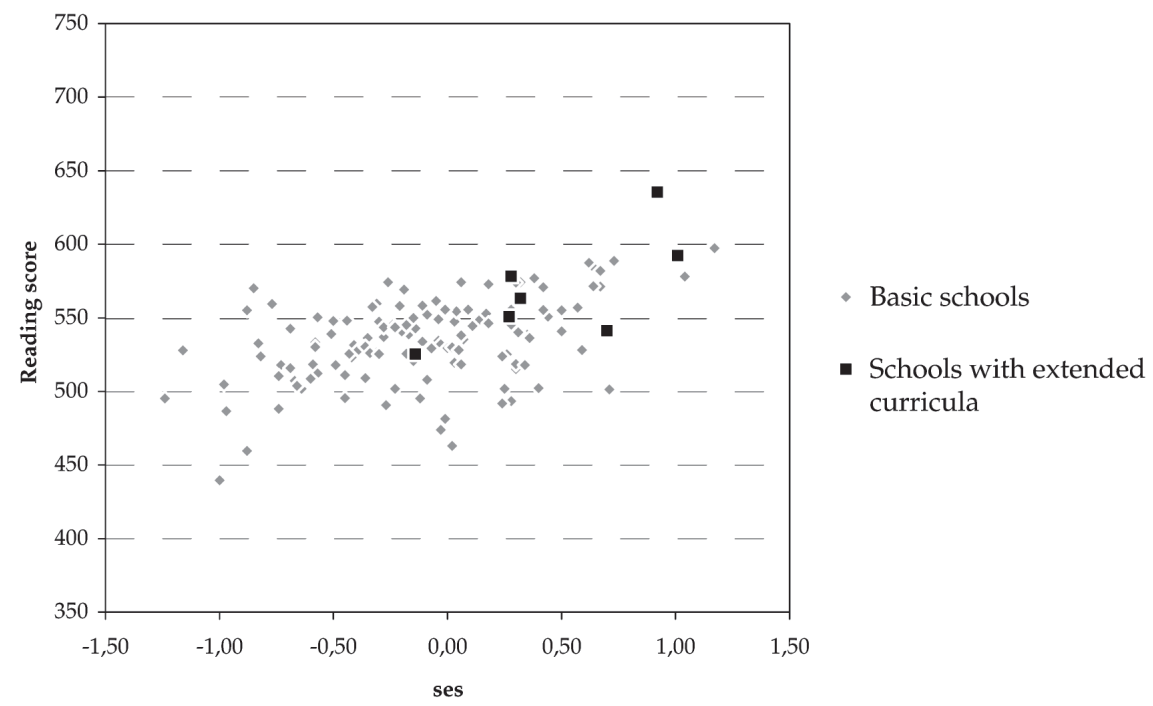


Figure 5. School profiles for Czech schools for grade 8 (TIMSS)

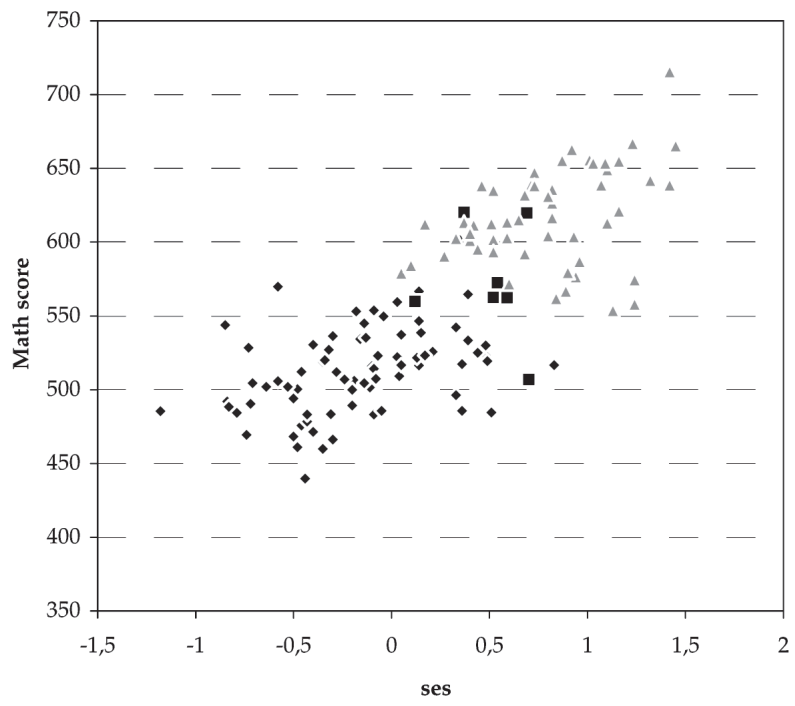

- Basic schools

- Schools with extended curricula

A M-Y gymnasia

Figure 6. School profiles for Czech schools for grade 10 (PISA)

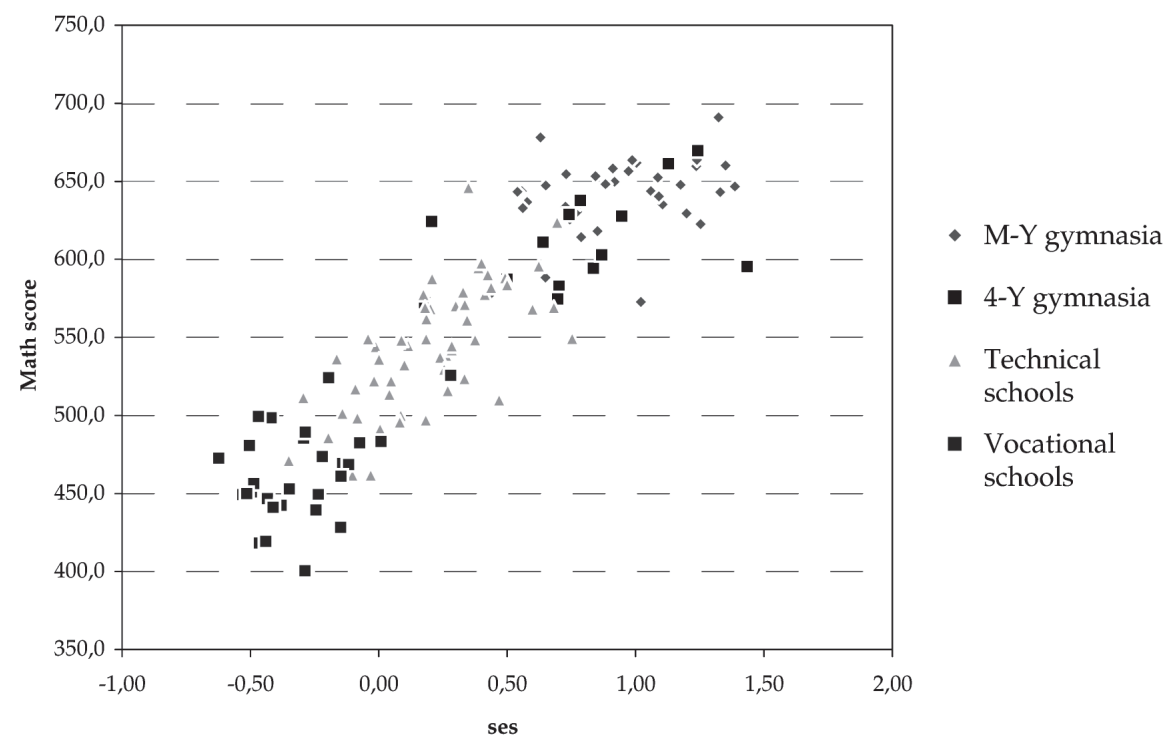




\section{Teaching attitudes}

Studies of the impact of homogenous grouping on student achievement show that teaching methods and teacher beliefs and attitudes significantly contribute to the widening of the gap between the higher and lower achieving classes [Harlen and Malcolm 1999; Slavin 1990]. Logically, in non-tracked systems teachers have to find different ways of educating all children, and they have to use teaching methods suitable for teaching in heterogeneous classrooms because they cannot avoid this responsibility by sending students with a poorer performance to special schools or classrooms. I tried to check this hypothesis on the data from large-scale surveys. Unfortunately, only few variables collected in these surveys could be used to verify this hypothesis. In Table 6 the results of the analysis are presented. Countries were divided into three groups according to the age at the time of the first selection in the education system: group 1 - first selection at the age of 10-11, group 2 - first selection at the age of 12-14, group 3 - first selection at the age of 15-16. The division of the countries is shown in appendix B.

Although the data available from questionnaire surveys accompanying large-scale studies cannot provide a complete picture about the teaching methods and attitudes in different education systems, the results show some distinct

Table 6. Selected indicators on teacher support for systems with various levels of tracking

\begin{tabular}{|c|c|c|c|}
\hline & Group 1 & Group 2 & group 3 \\
\hline & percentage of teachers & & \\
\hline $\begin{array}{l}\text { Differentiated reading materials } \\
\text { (PIRLS TQ) }\end{array}$ & 16.8 & 35.5 & 47.0 \\
\hline Availability of teaching aid (PIRLS TQ) & 10.0 & 31.5 & 50.1 \\
\hline \multirow{2}{*}{$\begin{array}{l}\text { Availability of a reading specialist } \\
\text { (PIRLS TQ) }\end{array}$} & 17.0 & 45.0 & 54.0 \\
\hline & percentage of students & & \\
\hline $\begin{array}{l}\text { Teacher interested in every student's } \\
\text { learning (PISA StQ) }\end{array}$ & 54.7 & 57.3 & 59.1 \\
\hline \multirow{2}{*}{$\begin{array}{l}\text { Teacher helps students with learning } \\
\text { (PISA StQ) }\end{array}$} & 63.8 & 65.3 & 79.5 \\
\hline & standardised score & & \\
\hline \multirow[t]{2}{*}{ Index of teacher support (PISA 2003 StQ) } & $-0,102$ & $-0,075$ & 0,061 \\
\hline & percentage of teachers & & \\
\hline $\begin{array}{l}\text { Some students have a talent for science, } \\
\text { others do not (TIMSS TQ) }\end{array}$ & 74.8 & 59.3 & 65.0 \\
\hline
\end{tabular}


Table 7. Selected indicators on teacher support for systems with various levels of tracking in the Czech Republic, Canada, Sweden, and Finland

\begin{tabular}{|c|c|c|c|c|}
\hline & CZE & CAN & SWE & FIN \\
\hline & percentage of teachers & & & \\
\hline $\begin{array}{l}\text { Differentiated reading materials } \\
\text { (PIRLS TQ) }\end{array}$ & 9 & 22 & 62 & \\
\hline Availability of teaching aid (PIRLS TQ) & 10 & 42 & 51 & \\
\hline \multirow{2}{*}{$\begin{array}{l}\text { Availability of a reading specialist } \\
\text { (PIRLS TQ) }\end{array}$} & 25 & 52 & 82 & \\
\hline & percentage of students & & & \\
\hline $\begin{array}{l}\text { Teacher interested in every student's } \\
\text { learning (PISA StQ) }\end{array}$ & 45 & 63 & 54 & 69 \\
\hline \multirow[t]{2}{*}{ Teacher helps students (PISA StQ) } & 55 & 87 & 87 & 87 \\
\hline & standardised score & & & \\
\hline \multirow{2}{*}{$\begin{array}{l}\text { Index of teacher support } \\
\text { (PISA } 2003 \text { StQ) }\end{array}$} & $-0,24$ & 0,27 & 0,67 & 0,20 \\
\hline & percentage of teachers & & & \\
\hline $\begin{array}{l}\text { Some students have talent, } \\
\text { others do not (TIMSS TQ) }\end{array}$ & 85 & 64 & & 54 \\
\hline
\end{tabular}

differences, especially between education systems at both extreme ends (the differences between all the variables shown in the table are statistically significant). The findings confirm the third hypothesis. Teachers in systems that do not track children more often use differentiated materials for students and work with teaching aids and reading specialists. They give students more help and support. Some differences were revealed also in the proportion of teachers who believe that some students possess a gift for sciences and others do not. One can assume that teachers who share this assumption may invest less effort in education of children 'without talent'. Table 7 shows the differences in teacher support between the Czech Republic, Nordic countries, and Canada. The differences between the values for the Czech Republic and for the other countries are statistically significant. 


\section{Conclusion}

The aim of this paper was to explore the development of the relationship between a student's achievement and his/her socio-economic status at different stages in the educational career in the Czech Republic. The reference countries used were the Nordic countries (Sweden and Finland) and Canada. These countries exhibit similar student performance and similar variation in socio-economic background and at the same time - unlike the Czech Republic - do not track children till the age of 16 .

The results show that at the primary school level (where tracking in the Czech education system only starts) the relationship between a student's achievement and his/her socio-economic status is comparable in all the analysed countries. In higher grades the socio-economic gradient in the Czech Republic is steeper than in Finland, Sweden, and Canada, and the Czech Republic also exhibits higher variation in student achievement than Finland and Canada.

In multilevel analysis, the Czech Republic also exhibits evidence of a much higher influence of the social composition of students in individual schools on student achievement than all the countries in the comparison. The school profiles show that the distribution of students to particular school types follows the socioeconomic status of the students.

The analysis also supported the hypothesis that the relationship between a student's attainment and his/her socio-economic status is strengthened not only by the structure of the education system (=early tracking) but also by the teaching methods and teacher attitudes. The data show that teachers in non-tracked systems more often differentiate teaching, use remedial methods, and give students better support. However, the questionnaire survey used in the international large-scale surveys provides only a limited amount of information in this area. In order to explore the differences between systems with different levels of tracking in this field further investigation would be needed.

JANA StraKovÁ graduated from the Faculty of Mathematics and Physics of Charles University in Prague. In the 1990s she was responsible for the coordination of most of the international large-scale surveys in student achievement carried out in the Czech Republic (IEA RLS, IEA TIMSS, IEA CIVICS, IEA SITES, PISA 2000). Since 2002 she has been working in the Department of Sociology of Education and Social Stratification at the Institute of Sociology of the Academy of Sciences of the Czech Republic, where she coordinates the Czech longitudinal survey launched with the PISA 2003. Educational inequalities is one of her main research interests. She is a member of the Institute for Social and Economical Analyses, where she is engaged in educational research leading to recommendations for education policy. 


\section{References}

Beaton, A., I. V. S. Mullis, M. O. Martin, E. J. Gonzalez, D. Kelly, T. Smith. 1997a. Mathematics Achievement in the Middle School Years: IEA's Third International Mathematics and Science Study. Chestnut Hill: Boston College.

Beaton, A., M. O. Martin, I. V. S. Mullis, E. J. Gonzalez, T. Smith, D. Kelly. 1997b. Science Achievement in the Middle School Years: IEA's Third International Mathematics and Science Study. Chestnut Hill: Boston College.

EGREES. 2006. Equity in European Educational Systems (A set of indicators). Liège: Service de Pédagogie théorique et expérimentale.

Erikson, R. and J. Jonsson. 1996. 'Explaining Class Inequality in Education. The Swedish Test Case.' Pp. 1-64 in Can Education be Equalized? The Swedish case, edited by R. Erikson and J. Jonsson. Boulder, USA: Westview Press.

Hambleton, R. K., H. Swaminathan and H. J. Rogers. 1991. Fundaments of Item Response Theory. London: Sage Publications.

Harlen, W. and H. Malcolm. 1999. Setting and Streaming. Edinburgh: The Scottish Council for Research in Education.

Hutchmaker, W., D. Cochrane and N. Bottani. (eds.) 2001. In Pursuit of Equity in Education. Dordrecht: Kluwer Academic Publishers.

Key Data on Education in the European Union 2004. 2004. Luxembourg: Office for Official Publications of the European Communities.

Martin, M. O., I. V. S. Mullis, A. Beaton, E. J. Gonzalez, T. Smith and D. Kelly. 1997. Science Achievement in the Primary School Years: IEA's Third International Mathematics and Science Study. Chestnut Hill: Boston College.

Matějů, P. and J. Straková. (eds.) 2003. Vyšší vzdělání jen pro elitu? (Higher Education for Elites Only?). Prague: ISEA.

Matějů, P., B. Reháková and N. Simonová. 2003. 'Transition to University under Communism and after Its Demise. The Role of Socio-economic Background in the Transition between Secondary and Tertiary education in the Czech Republic 1948-1998.' Sociologický časopis/Czech Sociological Review 39 (3): 310-324.

Mullis, I. V. S., M. O. Martin, A. Beaton, E. J. Gonzalez, D. Kelly and T. Smith. 1997. Mathematics Achievement in the Primary School Years: IEA's Third International Mathematics and Science Study. Chestnut Hill: Boston College.

Mullis, I. V. S., M. O. Martin, E. J. Gonzales, K. D. Gregory, T. A. Smith, S. J.Chrostowski, R. A Garden and K. M. O'Connor. 2000a. TIMSS 1999 International Science Report. Chestnut Hill: Boston College.

Mullis, I. V. S., M. O. Martin, E. J. Gonzales, K. D. Gregory, R.A Garden, K.M. O'Connor, S. J. Chrostowski and T. A. Smith. 2000b. TIMSS 1999 International Mathematics Report. Chestnut Hill: Boston College.

Mullis, I. V. S., M. O. Martin, E. J. Gonzales and A. M. Kennedy. 2003. PIRLS 2001 International Report. Chestnut Hill: Boston College.

Nováčková, J. 2001. Mýty ve vzdělávání.(Myths in Education) Kroměříž: Spirála.

OECD. 1997. Education and Equity in the OECD Countries. Paris: OECD.

OECD. 2001. Knowledge and Skills for Life: First Results from PISA 2000. Paris: OECD.

OECD. 2004a. Learning for Tomorrow's World. First Results from PISA 2003. Paris: OECD.

OECD. 2004b. What Makes School Systems Perform? Paris: OECD.

OECD. 2005a. Education at a Glance 2005. Paris: OECD.

OECD. 2005b. School Factors Related to Quality and Equity. Results from PISA 2000.

Paris: OECD.

OECD. 2006. Education at a Glance 2006. Paris: OECD. 
Pekkarinen, T., R. Uusitalo and S. Pekkala. 2006. 'Educational Policy and Intergenerational Income Mobility: Evidence from Finnish School Reform.' IZA Discussion Paper No. 2204.

Slavin, R. E. 1990. 'Achievement Effects on Ability Grouping and Student Achievement in Secondary Schools: A Best Evidence Synthesis.' Review of Educational Research 60 (3): 471-499.

Wildt-Persson, A. and P. G. Rosengren. 2001. 'Equity and Equivalence in the Swedish School System.' Pp. 299-322 in In Pursuit of Equity in Education, edited by W. Hutchmaker, D. Cochrane and N. Bottani. Dordrecht: Kluwer Academic Publishers.

Wilms, J. D. 1999. 'Basic Concepts in Hierarchical Linear Modelling with Applications for Policy Analysis.' Pp. 473-493 in Handbook of Educational Policy, edited by G. J. Cizek. New York: Academic Press.

Wilms, J. D. 2003. Ten Hypotheses about Socioeconomic Gradients and Community Differences in Children's Developmental Outcomes. Ottawa, Canada: Applied Research Branch of Human Resources Development Canada. 


\section{Appendix A}

Structure of the education system, Czech Republic (2004/2005)

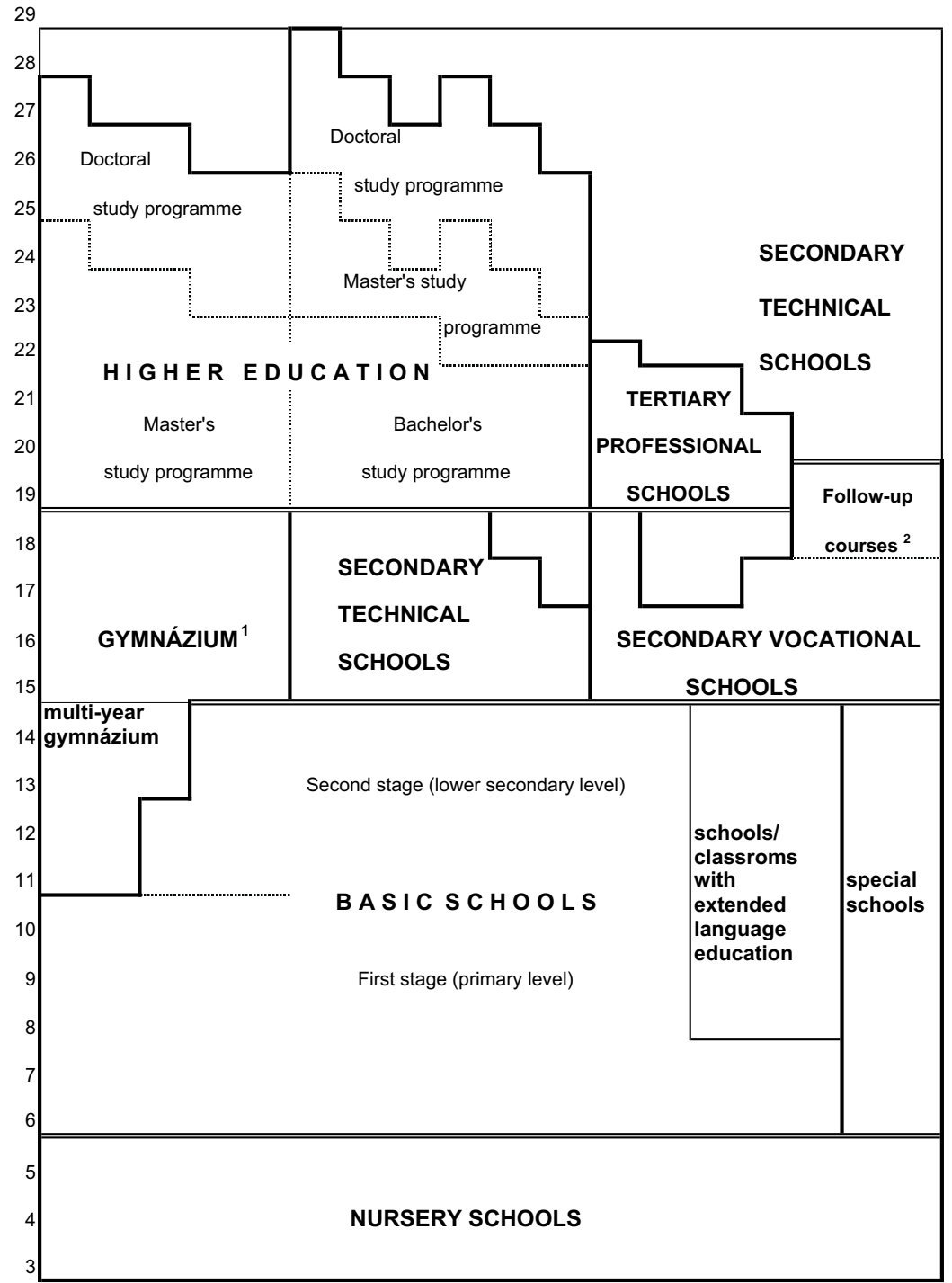

1. Compulsory education lasts nine years. The majority of pupils complete it at basic schools. Pupils who study at a multi-year gymnázium complete it in relevant years of gymnázium.

2. A follow-up study is designed for graduates of three-year courses at secondary vocational schools. It gives them the opportunity to improve their qualifications and pass maturitní zkouška (school-leaving exam), which gives them access to higher education. 


\section{Appendix B}

Table B1. Countries according to the age which the first selection in the education system takes place

\begin{tabular}{lcc}
\hline Country & age of first selection & group \\
\hline Austria, Germany & 10 & 1 \\
Czech Republic, Slovak Republic, Hungary, Turkey & 11 & 1 \\
& & \\
Mexico, Belgium, Netherlands, Switzerland & 12 & 2 \\
Luxembourg & 13 & 2 \\
Italy, Korea & 14 & 3 \\
Greece, Portugal, France, Ireland, Japan, Poland & & 3 \\
Norway, Australia, Canada, Denmark, Finland, & 15 & \\
Iceland, New Zealand, Spain, Sweden, United & 16 & \\
Kingdom, United States & & \\
\hline
\end{tabular}

Source: Education at a Glance 2005. 